DOI: $10.24234 /$ wisdom.v15i2.340

Natella PAVLENKO,

Irina UTIUZH,

Karim EL GUESSAB,

Parviz Teiiub ogly VELIIEV

\title{
POSTMODERN INTERPRETATION OF THE METAPHYSICAL GROUNDS OF THE WEALTH PHENOMENON
}

\begin{abstract}
The article deals with the methodological interpretation of the phenomenon of wealth that is represented by various philosophical systems: the ideas of Nietzschean philosophy, theoretical models of analytical attitudes, interpretation in specific categories of existentialism and other conceptual aspects.

The philosophical thought of the twentieth century that gave rise to one of the controversial and supercritical paradigms - postmodern philosophy is presented. Exactly within this philosophy, the structuralist and poststructuralist discourse is formed.

The authors present the analysis of the works of the classics of postmodern philosophy, G. Bataille and M. Foucault, who attempted to reveal and explain the paradox and tragedy of modern man and social relations.

The article emphasizes that there is the unresolved question: why diverse related philosophical topics are united within the framework of a single discourse, the discourse of the socio-philosophical interpretation of wealth.
\end{abstract}

Keywords: social discourse, "modus of ownership", mythologeme of wealth, anthropological mechanism, ambivalent nature of man, economic cathexis.

\section{Introduction}

We tend to talk about the fundamental ontological connection of man with the world, the involvement of the vital forces of man into existence, which forms a kind of force field, the field of action of human forces, essential forces - to accumulate and waste, whether energy or material objects, i.e., in other words, wealth.

We tend to believe that the problem of socio-philosophical study of the phenomenon of wealth is the result of historical development, namely specific historical events, especially those of the XX-XXI centuries. The modern problem of philosophy of wealth was generated by the total "modus of ownership", which corrodes and destroys the spiritual culture of postmodern society.

The mystifying status of wealth in modern capitalism destroys the social, moral, and human; therefore the task of progressive humanity is to preserve itself, which is especially relevant in the context of the pandemic, when wealth should be considered as a source of welfare, allowing the 
man to correlate his goals and actions. Unfortunately, it is hardly possible in mass society.

The idea of advancing the myth of wealth by modern capitalism urges us to address the issue of the metaphysical grounds of the mythologeme of wealth, which today has developed into the ideologeme of modern society and is implemented in the poststructuralist paradigm of philosophy.

The idea of a society of total domination of capital lies in continuous production not only of "use values" but of everything, including services, feelings, desires and even the human soul. According to postmodernists, everything is production, production of productions, actions and passions, production of registrations, distributions and restrictions, production of consumptions, pleasures, anxiety and suffering Foucault (1999).

Therefore, identification of the metaphysical grounds of the economic cathexis in the modern era is more relevant than ever. Wealth is the mechanism that forms the structure of the contemporary economy. In this regard, we have a reason to refer to the works of the classics of postmodern philosophy, G. Bataille and M. Foucault, who attempted to reveal and explain the paradox and tragedy of modern man, in whose nature there is the mechanism that shapes the being striving for gain and enrichment and truly a man, who, at the heart of his existence, represents decency, work, care for children, benevolence and loyalty to people (Bataille, 1994).

Philosophers in their theories of anthropogenesis and sociogenesis reveal the concept of "general economy", "the future of the capitalism". They show the value of wealth in the life of contemporary western European society.

Thus, the article aims to analyse the formation of the mythologeme-ideologeme of wealth in human consciousness and society through the analysis of the ambivalent human nature and the result of the struggle of the opposite sides of human nature in creating the social.

\section{The Methodological Interpretation of the Wealth Phenomenon Represented by \\ G. Bataille's Poststructuralist Tradition}

The formation of the human, moral, social through rationalization and receipt of labour, result and wealth is an anthropological mechanism of departure from animality in human nature, and it is known that animality is the starting point of human evolution, from which man takes his corporeality and all manifestations associated with it.

If man surrendered himself to immanence, freeing the natural world from his power, he would change his humanity and return to the original state: innermost animality. Therefore, it is impossible to be a person without remaining a thing (Bataille, 2000). The modern world has elevated rationality, labour and the phenomenon of wealth to the status of the Absolute and social technology of existence, i.e. everything has a market value and can be exchanged for money or welfare.

The ideologization of the concept of wealth is related to the fact that people needed justifiable meanings of life. Individual existence and service to the common good were emphasized and actively integrated into the system of capitalist relations. Consequently, the capitalist enterprise made the most of the justifiable aspects of human integration into life.

Postmodern culture presents the space of capitalism and wealth, which have become the desired type of social order or "the best of all systems" (Boltanski \& Chiapello, 2011, p. 43). 
Ideologization of wealth is closely related to the principle of justice. This principle enables a person to join the social capitalist system of relations. The main postulates of such a system are as follows: "You are the best, you can never quit, if you fell down - stand up", etc. These meanings give a person moral justifications to strive for gain and enrichment. Moral arguments are developed in order to legitimize the business and entrepreneurial practices in everyday life.

Further, ideologization of the concept of wealth results in the formation of mass production and mass consumption, where the emphasis of enrichment is shifted to a particular person and enterprise, which is repaid by the guarantees of security and stability of the life of worker and director (manager).

Under current conditions, wealth is what people value, what expands the choice of man, his alternative opportunities. It is impossible to reduce wealth only to material values, i.e. to material wealth, but, unfortunately, the time goes by, and the spiritual and moral degradation of society is so apparent that we consistently pose the questions: What is next? Where is humanity? Therefore, we address the metaphysical aspects of the search for answers to the questions: what is the essence of man? Is man good or greedy and cruel? Man is increasingly alienated from himself, surrendering to the power of the processes, which he is no longer able to control and the consequences of which are beginning to frighten man himself.

The problem of overproduction, and, consequently, the complexity of production destruction, takes the man into the state of a slave and forces him to agree with the cause of production. According to G. Bataille (1989), “...the moment when consciousness, reflecting on itself, reveals itself to itself and sees production destined to be consumed is precisely when the world of production no longer knows what to do with its products" (p. 84). Therefore, in order to preserve the course of the economic mechanism, we have to endlessly consume or destroy the product of labour (Bataille, 2000). This is what modern Homo economicus is destined to do; since there is no time and opportunity to search for the grounds of happiness and for humanity in himself, he has to convince himself and others that happiness lies in production and consumption. Therefore, the system of relations between man and wealth, as the result and purpose of the capitalist system of production, becomes the focus of research carried out in the scientific world.

The above reflections refer to Bataille's existentialist methodology. The philosophy of G. Bataille is one of the essential sources for the development of structuralism and poststructuralism, which is of great importance in our study and will build the logic of socio-cultural transformation of the phenomenon of wealth.

Bataille's socio-philosophical interpretation of the problem of the wealth substance, its primary basis and source are of utmost interest. His methodology, presenting the analysis of the human nature ambivalence, brings to the forefront the issues of the ratio of humanity and animality and the transition mechanism from animality to humanity. As we have already specified, according to G. Bataille, the mechanism of translation of animal, furious into a human is labour. Labour as rationalization and rational orderliness is opposed to natural rage, animal impulses that regularly storm in man's soul. Therefore, the nature of man is neither good nor evil; man is given the instrument of humanity - reason, which makes man happy and unhappy at the same time.

In the introductory article by S. Zenkin to the book "The Accursed Share: Sacral Sociolo- 
gy" by G. Bataille we find the confirmation of this thesis: “...man necessarily contains animality, which he rejects, separates from himself. Describing animal in man as a being for whom the things in existence (the outer world) are open but inaccessible; in other words, animal-man is open in inaccessibility and non-transparency, that is, as it were, in non-relation" (Bataille, 2006, p. 16). Such openness without disclosure is determined by the poverty of the animal world in contrast to the formation of the world, characteristic of the man. An animal cannot cognize the world as such with this "world of poverty", it is completely absorbed in a particular stimulus (food, enemy, etc.), which temporarily puts him out of balance. Obviously, “... animal does not open into the world as Dasein, but is ecstatically drawn outward, into an expressiveness that profoundly shakes its whole being" (Bataille, 2006, p. 17).

The human experience of the world "...is simply opened by cessation, deactivation of the animal relation to the stimulus" (Bataille, 2006, p. 17). The world "opens up" to man as he can distract himself from the immediate stimulus, suspend and restrain the direct action of his own passions, that is, to overcome (but not to remove!) animality in himself.

This is the first but not the last act of anthropogenesis, as, within man, a new division occurs, which may coincide (erroneously) in his own eyes with the division of man and animal. The attitude of man to an animal is dual, ambivalent for a specific reason: he simultaneously sees in animal both his predecessor in the biological evolution and the symbol of supreme freedom, which he associates with a purely human sacred state, unknown to animal" (Bataille, 2006).

Bataille's postulate of the essence of prelogical affective nature is explicitly deduced by A. Shutov (2016), a researcher of the philosophy of G. Bataille. He argues that “...existentialism considers the situation of cultural crisis and existential disorientation as something unequivocally negative and requiring overcoming and order, G. Bataille, on the contrary, views it as the moment when man, being sometimes unable to independently orientate himself in the world around him, relying solely on rational thinking and estimation, starts to follow prelogical affective impulses and drives, which serve as new guidelines for his behaviour. According to G. Bataille, such impulses and drives are an essential part of the human being. It is not necessary to search for the ways of their displacement or overcoming, but, having understood what place they occupy in modern life, to bring these impulses out from under social prohibition and create conditions for their controlled expression and satisfaction" (p. 9).

If we turn to the literary heritage of G. Bataille (1988), he indicates: "The living organism ordinarily receives more energy than is necessary for maintaining life; the excess energy (wealth) can be used for the growth of a system (e.g., an organism); if the system can no longer grow, if the excess cannot be completely absorbed in its growth, it must be necessarily lost without profit; it must be spent, willingly or not, gloriously or catastrophically" (p. 21). The history of life on earth is mainly the effect of wild exuberance; the dominant event is the development of luxury, the production of increasingly burdensome forms of life.

According to G. Bataille, "catastrophically" means war; it is a war that can become a consumer of excess economy, but this is beyond the topic of our study. Here, we would like to note that according to this logic, there are two types of wealth: "...there are two ways to understand wealth: traditional (Darwinian), in which wealth is understood as accumulation and saving, and 
transgressive (Bataille-Nietzschean), considering wealth as something excessive, subject to squandering, gift-giving, destruction. G. Bataille, in the Nietzschean vein, argues that natural economy is not built on accumulation, but on waste, even where, at first glance, it seems that there occurs reproduction of resources" (Kashtanova, 2016, p. 111).

Reason and morality form the rules which follow from the nature of the profane world. It is morality that condemns extreme forms of demonstrative destruction of wealth, which was one of the ways to touch the sacred world (animal world) for a while, even artificially, to become immanent to nature.

G. Bataille (2000) declares that the split of the inner order (order of the animal world) and the order of things (order of the profane world) resulted in the liberation of production from its archaic purpose (unproductive destruction of excessive products) and the moral rules of coexistence (deeds for the sake of the future result, not of momentary pleasure). According to G. Bataille (2000), this is what exactly enabled the emergence of the prospect and real possibility in the future to allocate the surplus of production activity to re-equipment of production for capitalist accumulation.

Therefore, the essence of sacralisation in rationalisation by labour (and through labour) creates an orderly activity, which becomes human activity. Profanity will appear later, where labour and wealth will accept rather negative meanings of existence. Bataille (1989) assumes that in the meantime, where labour exists, the thing exists as well (i.e. accumulation - wealth), and vice versa. The author pays great attention to the appearance of tools that will create the future wealth of man. Bataille (1989) even shows the mechanism and goal-setting principles of accu- mulation: "The tool has no value in itself - like the subject, or the world, or the elements that are of the same nature as the subject or the world but only in relation to an anticipated result. The time, spent in making it, directly establishes its utility, its subordination to the one who uses it with an end in view, and its subordination to this end; at the same time, it establishes the clear distinction between the end and the means, and it does so in the very terms that its appearance has defined. Unfortunately, the end is thus given in terms of the means, in terms of utility. This is one of the most remarkable and most fateful aberrations of language. The purpose of a tool's use always has the same meaning as the tool's use: a utility is assigned to it in turn and so on. The stick digs the ground in order to ensure the growth of a plant; the plant is cultivated in order to be eaten; it is eaten in order to maintain the life of the one who cultivates it..." (p. 28).

Thus, the tool is part of the purpose and the result to be achieved. Due to the appearance of tools, man becomes aware of himself in time and meanings of existence, the past, present and future appear; within this continuum of time, the man begins to regard himself as a project directed to the future. Based on the awareness of temporality, man becomes aware of his finiteness mortality. G. Bataille (1989) insists that it is the fear of death that drives a man to obtain benefits. But sovereign man does not succumb to death; he cannot live in this enslaving anxiety-inducing flight from death, which is the beginning of slavery. The desire for efficiency and utility is the factor that ensures labour and wealth.

S. Kashtanova (2016) declares that social being is built on the contrast with the natural order: in nature, death carries out its destruction indiscriminately, in society, on the contrary, maintenance and reproduction of life is at the 
forefront. This principle is also implemented at the level of the economic structure of society and is expressed in production and accumulation of material welfare, in pursuit of benefits and efficient labour activity.

At first glance, such is the case. However, the human world is different from the animal world in the absolutism of accumulation, i.e. wealth. The attempts to criticize this were made by G. Bataille and many other philosophers of the twentieth century who survived the war, crisis of spirituality, plague of greed, etc. In their philosophical doctrines, they are trying to save humanity - to educate and teach.

In his work, "The Accursed Share", G. Bataille (2006) defines labour and wealth as belonging to the man who preferred to live in slavery rather than die free. However, at the same time, the philosopher also gives a positive characteristic of labour as how man developed from animality and identified himself as human. Owing to the observance of prohibitions, which resulted from labour activity and the need for accumulation, people ceased to perceive themselves as animals.

G. Bataille (2006) argues that the extent to which man accepts utilitarian ethics means the sky is closed to him, and the Sun is only a source of calories. It is the society of man of "profit" that was the first to oppose glorious deeds (the cult of giving and sacrificing). Slave psychology asserts that fame is insignificant in comparison to profit. However, Bataille hopes and believes that modern man will understand that it is glorious deeds that give the meaning to life and make up its value, and actions, which aim for profit only, are worth nothing.

He writes: “. . accumulation was only a delay, a shrinking back from the inevitable term, where the accumulated wealth has value only in the instant. ...energy finally can only be wasted" (Bataille, 1988, p. 11). According to Bataille (1988), it is the principle of "general economy", in which "expenditure" ("consumption") of wealth is more important than production.

The world involved in endless consumption could be called sacred (the philosopher does not say this, though). The author shows the transition to the profane (which we have already mentioned), introducing the metaphors describing "the Earth as "cold", "stingy" and "greedy", where man is destined to eternal work, service and all kinds of profit commensuration. The world of labour has determined the importance of the further operation result but not the truth of the current moment, as the worker lives in order to work without enjoying the fruits of his labour (Bataille, 1988).

G. Bataille focused his scientific interest on the socially limiting situations of human action; namely, he tells us that man lives in the mode of unproductive waste rather than according to the principles of saving resources and utility. Excess energy is expended in the search for belonging. It is the thirst for involvement, "need for another" (E. Fromm), that is the ground for the social, which G. Bataille tries to explain in terms of "bioeconomics". Of course, this conceptual space is based on the mythologeme of wealth.

Like many other modern researchers, G. Bataille considered the phenomenon of wealth as a mythologeme of "general welfare" or Affluent Society (J. Galbraith). It is evident that this capitalist system completely denies squandering, insisting upon and creating the system of total accumulation. In work "Revolutionary Wealth", A. Toffler points to it directly: "as soon as people learned to create surpluses of production, the first real system of wealth became possible" (Toffler \& Toffler, 2008, p. 36). 
Under present conditions, this system of wealth is no longer a mythologeme, but the reality of existence, the factor that created the consumer society. Having generated consumer hedonism (consumerism), the system of wealth creates complete indifference to high values "to what religion begins with" (Baudrillard, 2000, p. 146).

This is the reason why in Bataille's logic, the emergence of the phenomenon of wealth begins with the analysis of religious consciousness. Presenting the prospects for an alternative understanding of economic processes, the author begins with the analysis of anthropogenesis problems and proposes the thesis of the fundamental difference between animality and humanity due to immanence inherent in the animal world and the absence of subject-object relations realized in the order of things. According to G. Bataille, man expresses his anguish for immanence through sacrifice.

A. Zygmont (2018) also argues that "the world is full of violence, but man is deprived of it and only resorts to consumption because of the nostalgia immanent in him for unity with the world and freedom; in order to merge with the order of things, he turns to its derivative - sacrifice" (p. 160).

G. Bataille (2000) declares that the purpose of sacrifice is to break the chain of subject-object production relations of utility, to do something insane, utterly useless in the tradition of rationality, thereby feeling the world in which an unaccountable whim reigns.

In the modern consumer society, our entire life becomes an unaccountable whim, where shopping and an overwhelming desire for possession, which does not fit our realities (amount of money available), the result for society in the monopoly of pleasure, which kills any ethics, any appeals to conscience and duty, even professional one. In signs of its vitality - wealth and poverty, modern society falls into the nostalgia "for the impossible."

\section{The Methodological Interpretation of the Wealth Phenomenon Represented by M. Foucault's Poststructuralist Tradition}

M. Foucault analyses modern society entirely in the spirit of postmodern cynicism, which also allows us to see the reasons for an "economic cathexis". He is aware of the fact that the ideologeme of wealth appears as a justifiable sense in the system of capitalist relations, being realized in the principle of justice, which structures the world of individual and corporate.

It is noteworthy that any policy of social governance is based on the system of philosophical and ideological senses and values that meet the needs of the critical citizenry in society, as long as everybody believes in these values freely. According to M. Foucault, all knowledge is shaped by power, and therefore he considers the analysis of the phenomenon of wealth through the transformation of the power structure and mechanisms. History shows that the socio-cultural ideology is focused on strengthening power and increasing wealth to the utmost.

The above stated can be proved by the thesis of C. Gordon (1987) that was mentioned in his article. The author declares that Foucault suggests that a decisive factor in this epistemological reconfiguration is played by the introduction of a new concept of interest. Political economy is inspired, particularly in its quality as a reflection on the history and formation of civil society, by a new realization (Gordon, 1987).

In turn, P. Armstrong (1994) declared that Foucault also depicts disciplinary regimes as op- 
erating primarily through a discursive constitution of the subject.

M. Foucault (1998) begins his social-philosophical analysis of the phenomenon of wealth by revealing the correlation between the things and words, i.e. he focuses on the conceptual and descriptive methodology. However, discontent with this stance, he materializes his philosophy into the structure of the corporeal, which could give a feasible explanation of why man aspires to be wealthy.

This is what M. Foucault portrays in his work "The Birth of the Clinic", in which he declares that the attitude to the body as to the benefit that earns capital is being shaped. The active development of capitalism resulted in a rapid production growth, which predetermined the need for a social process that could support this growth on account of employable population health. The authorities needed to create a new ideology, the ideology of capitalism, which is based on health as pleasure, happiness and motivation for the love of work. The outcomes were a simulation of the love of work, which earns money; and the love of money, which becomes deeper than one person's love for another. A qualitatively new kind of institutions that needed to be politically effective appeared, and there emerged a new society that became an official body of collective consciousness.

M. Foucault (1998) suggests considering the clinic as such an institution, which can maintain the health of man through man's obedience to medical practitioners, that is, specialists who understand what health and disease are and are able to treat.

Thus, the emerging capitalist system employs medicine and shapes new senses of life based on health as salvation.

According to Foucault (1998), economists unite with representatives of medicine, the Committee on Poverty (Comité de Mendicité) is created to reorganize the system of treatment, which would not destroy the nation, but on the contrary, enrich it and make money. It appeared that it was more profitable to distribute funds not to productive wealth but to the very principle of wealth labour; in other words, to force the population to work, especially its poor layer. Therefore, overcoming numerous obstacles, the structure is born where the laws regulate professions related to the population's health. This structure performs a dual function: firstly, it is a place of care and solicitude for the sick, and secondly, it is one of wealth accumulation through coercion, discipline, manipulation, both with the body and mind.

"The Birth of the Clinic" describes the emergence of the ideology, which plays a decisive role in the restructuring of the society of that time, namely the birth of capitalist society, which is closely related to the need for social protection in an ambiguous sense: as protection of wealth and protection of the rich from the poor. The clinic is exactly the place where disease and poverty come together to create the protection of man. With the advent of clinics, repressive coercion and subordination of the poor occur, according to M. Foucault (1998), not as a cruel tyranny, but as something veiled under careful parental care. This concern is manifested in the supervision at the state level of the doctor, as of that who does not produce values but treats those who produce them.

Of course, the creation of a new medicalization system required huge material costs. It is known, there is no conscious expenditure without the purpose and the consequence of obtaining greater benefits. According to Foucault (1998), by spending money on treatment of the poor, first and foremost, the rich pay for a better study 
of diseases he could potentially develop. Therefore, what seems to be a charity for the poor is transformed into useful knowledge for the rich.

M. Foucault (1998) states that health replaced salvation through the interaction of the rich with the poor. This interaction gave rise to new senses of existence: through the knowledge of the body. Medicalization has become the dominant of modern culture and an indicator of man's civilization, his standard of living and wealth. In his book "The Birth of the Clinic", not only does M. Foucault present the emergence of the clinic as a social institute of medicine, but also rationalizes it with the institute of power (the power of emerging capitalism, where body brings benefits, provides an opportunity of wealth accumulation, and, therefore the power is able to manipulate the man only through health, body, the formation of senses of life and death).

Therefore, M. Foucault's clinic is rationalized as an institution of power that limits the liberty of the sick in exchange for professional medical assistance in maintaining man's life and health. "The Birth of the Clinic" depicts the stimulation of disciplinary medicine development, which forms a disciplinary society. Thus, speaking of the dialogue between wealth and poverty, we state, following M. Foucault, that the discourse of any new knowledge existence is formed by wealthy people, who become power themselves, and the power forms money.

M. Foucault (1996) shows the role of the mechanism of violence against man in the search for and formation of boundless wealth, which establishes unliberty of man.

According to Foucault (1996), the era of suppression in the XVII century coincides with the development of capitalism. Therefore, all discourses are subject to bourgeois orders. In his work "The Will to Know", M. Foucault notes that investment of libidinousness in an economy should be considered as the chief pleasure: pleasure can only be found in work, in work solely. Everything else distracted man from his primary mission - work. Sex was approved only for reproduction, procreation of its kind, and, using the vocabulary of capitalism, for creation of labour, which gives money. Here, in establishing economically useful and politically regulated sexuality, Foucault sees the discourse of utility. However, he emphasizes the fact that restraining sexuality is not about asceticism, but on the contrary about the intensification of the body, its health, maximization of life. Cultivating the theme of sex with fear and prohibition, the government stimulates interest in the body, creates a class body with special care for its health and hygiene. Power over life was centred on the body, which, on the one hand, was perceived as a machine that had to be trained to optimize its capabilities and integrated into efficient economic systems, and on the other hand, the body should be taken care of as it reproduces labour force. Foucault tells us about the rise of the "Biopower" era, which creates a social body through care and by using institutions of the army, school, family and other numerous repressive formations. "Biopower" is undoubtedly a necessary element in the development of capitalism, which enables availability of the body for use and its obedience. The power ceases to speak through bloody repression over the body and starts to take care of the body.

In "The Will to Know", M. Foucault (1996) asserts that exorbitant labour, to which the West has taught the generations in order to produce, while other forms of labour provided accumulation of capital - subordinated people, creating subjects from them. That is a man absorbed in work does not feel that he is being subordinated. Labour plays the role of a repressive measure 
that restrains a person from realizing any desires and directs all his intentions only to labour. Another measure is the canonical (nuclear) family, as an instrument of political control and economic regulation.

Power acts as a clear boundary to define liberty. By restricting the liberty of man, power shows that liberty exists and that is its particular value. Providing man with a piece of liberty is another brand of power of care.

In his work "Madness and Civilization: A History of Insanity in the Age of Reason", Foucault (2010) argues that it is during the birth of capitalism that madness acquires new characteristics and features and starts to be perceived as a social problem, as a problem of social co-existence. Now, insanity is not just a disease, but a phenomenon that brings poverty and is peculiar to the class which refuses to accept the forms of bourgeois ethics, namely, to work and generate wealth. In order to overcome this phenomenon, asocial elements were excluded from society through their placement in specialised clinics. It was a kind of attempt to purge society of hostile elements. However, according to M. Foucault, it is important to determine what exactly acted as the regulator when the decision on isolation or liberation of a man was taken and why it was the Classical Age when insanity started to be perceived as a disease of the body that required a scientific study. M. Foucault argues that these "alien" elements were first created, born, and then isolated. It was clearly and efficiently shown to society that a person unable to work is insane and should be isolated from society to prevent its disintegration. That is, in the classical era, idlers were identified with the mad and related to the treated the world of Insanity. The medical perception of a disease comprehensively obeyed ethical intuition, and thus, in order to re- late madness with a sense of guilt and give madness a kind of sinful stigma, the insane were placed in clinics together with venereal patients. M. Foucault declares that the concept of insanity is not a historical category; it became a moral criticism. It was in the Classical Age, in the era of the birth of capitalism, when it became clear that isolation does not make an economic sense, it is necessary to liberate the poor and integrate them into society by turning them into a cheap labour force. According to M. Foucault, poverty becomes an economic phenomenon and is liberated from negative moral characteristics. It is necessary to take care of the poor, as with the emergence of industry, there appears a need for workers, and poverty caused by isolation becomes an integral part of the nation and the main component of wealth. Care homes for the poor appear, where assistance is only provided to those who are physically unable to work, the rest of the poor shall be provided with work. All these looked like care on the part of the authorities.

\section{Conclusions}

Summing up the results of our study of the metaphysical grounds of wealth, we conclude that the works by G. Bataille and M. Foucault, having become the classic examples of postmodernism philosophy, present the analysis of the original concepts of the Western civilization development based on ideology. The transformation of the psychological and social structures, described by G. Bataille and M. Foucault, enables revealing the metaphysical grounds of the phenomenon of wealth, which emerges as the rationalization in the social structure of Western societies, control over affective behaviour in human experience and alteration in the regulation of affects through external coercion and self- 
coercion.

The theoretical grounds for our article were the ideas stated by French philosophers G. Bataille and M. Foucault.

Having analysed G. Bataille's works, we can conclude that the philosopher was greatly influenced by the Marxist interpretation of anthropogenesis, which explains the significance he attached to the appearance of first tools of labour, natural waste, gift-giving and wealth.

G. Bataille's understanding of wealth is not limited to utility, accumulation and preservation of energy (i.e., wealth). According to Bataille, wealth is an unproductive waste; it is the expenditure of excess energy in the search for belonging. The sense of social involvement is the ground for the social and true wealth for further survival of man.

M. Foucault identifies the conceptual constants, which are used in the analysis of the phenomenon of wealth and form a binary discourse of understanding modern capitalism, namely: strengthening of powers and increasing of wealth, "capitalist rationality/irrationality", "Enlightenment", "capitalization of the unconscious", "capitalization of space and time". Obviously, M. Foucault focuses on the so-called discourses of power rather than on the economic premises for Western European humanism. It was the application of disciplinary practices that meant a well-coordinated organization of production, which enabled us to reveal the sociocultural dynamics of the phenomenon of wealth in the worldview tradition of Western European society.

\section{REFERENCES}

Armstrong, P. (1994). Influence of Michel Foucault on Accounting Research. Critical
Perspectives on Accounting, 5(1), 25-

55. doi.org/10.1006/cpac.1994.1003.

Bataille, G. (1988). The Accursed Share. An Essay on General Economy. New York: Zone Books. Retrieved March 02, 2019, from: https://www.filosofiadeldebito.it/wordpress/wp-content/uploads/2017/05/1988 Bataille-The-AccursedShare Essay-on-General-Economy.pdf.

Bataille, G. (1989). Theory of Religion. New York: Zone Books. Retrieved September 15, 2019, from: https://www.docdroid.net/IoXNuSH/259558558-georges-bataille-theory-of-religion.pdf.

Bataille, G. (1994). Literatura i zlo (Literature and Evil, in Russian). Moscow: Moscow University Press. Retrieved September 15, 2019, from: https://platona.net/load/knigi_po filosofii/postmoderni zm/literatura i zlo zhorzh bataj/54-10-4709.

Bataille, G. (2000). Teoriya religii. Literatura $i$ zlo (Theory of Religion. Literature and Evil, in Russian). Minsk: Sovremennyi literator. Retrieved June 20, 2019, from: https://klex.ru/etp.

Bataille, G. (2006). Proklyataya chast': sakral'naya sotsiologiya (The Accursed Share: Sacral Sociology, in Russian). Moscow: Ladomir. Retrieved July 11, 2019, from: https://studfiles.net/preview/1633907/.

Baudrillard, J. (2000). Obshchestvo potrebleniya: mify i struktury (The Consumer Society: Myths and Structures, in Russian). Moscow: Republic.

Boltanski, L., \& Chiapello, E. (2011). Novyi dukh kapitalizma (The New Spirit of Capitalism, in Russian). Moscow: No- 
voe literaturnoe obozrenie.

Foucault, M. (1996). Volia k istine po tu storonu znaniya vlasti i seksualnosti (The Will to Know: on the other Side of Knowledge, Power and Sexuality, in Russian). Moscow: Castal Press.

Foucault, M. (1998). Rozhdenie kliniki. (The Birth of the Clinic, in Russian). Moscow: Smysl. Retrieved May 15, 2019, from: https://www.litmir.me/br/?b=11$\underline{6390}$.

Foucault, M. (1999). Nadzirat' $i$ nakazyvat': Rozhdenie tyur "my (Discipline and Punish: The Birth of the Prison, in Russian). Moscow: Ad Marginem. Retrieved July 11, 2019, from: https://www.e-reading.club/book.php?book=95796.

Foucault, M. (2010). Bezumie i nerazumie. Istoriia bezumiia v klassicheskuiu epokhu (Madness and Civilization: A History of Insanity in the Age of Reason, in Russian). Moscow: "AST Moskva”. Retrieved May 12, 2019, from: http://booksonline.com.ua/view.php?book $=4$ $\underline{6516}$.

Gordon, C. (1987). The Soul of the Citizen: Max Weber and Michel Foucault on Rationality and Government. In S. Whimster \& S. Lask (Eds.), Max Weber: Rationality and Modernity. London: Allen \& Unwin. Retrieved January 08, 2019, from: https://www.academia.edu/1010-
0495/The Soul of the Citizen Max

Weber and Michel Foucault on Rati onality and Government.

Kashtanova, S. (2016). Transgressiya kak sotsial'no-filosofskoe ponyatie (Transgression as a Socio-Philosophical Concept, in Russian). PhD Thesis, Social Philosophy. Saint-Petersburg. Retrieved November 10, 2018, from: https://disser.$\underline{\text { spbu.ru/files/disser2/disser/J77qWd42 }}$ $\underline{\text { NC.pdf. }}$

Shutov, A. (2016). Predel'nyi opyt v geterologii Zhorzha Bataia (The Ultimate Experience in Georges Bataille's Heterology, in Russian). PhD Thesis, History of Philosophy. Moscow. Retrieved May 03, 2019, from: https://www.hse.ru/data/2016/07/20/1131819321.pdf.

Toffler, A. \& Toffler, H. (2008). Revoliutcionnoe bogatstvo: kak ono budet sozdano i kak ono izmenit nashu zhizn (Revolutionary Wealth. How it will be Created and how it will Change our Lives, in Russian). Moscow: AST Moskva.

Zygmont, A. (2018). Nasilie i sakral'noe v filosofii Zh. Bataia (Violence and the Sacred in G. Bataille's Philosophy, in Russian). PhD Thesis, History of Philosophy. Moscow. Retrieved December 15, 2018, from: https://iphras.ru/uplfile/zinaida/ROOTED/aspir/autoreferat/zig mont/zygmont dissertatsiya.pdf. 